\title{
Nuclear crisis and plastic surgery
}

\author{
Sir,
}

The problem of radiation exposure in nuclear crisis is an interesting topic. In the present day, the effect of Fukushima crisis on health is widely discussed, and the topic in plastic surgery should also be mentioned. There are few reports on this specific topic. Indeed, plastic surgery is useful in reconstruction of severely irradiated and burnt cases. Also, the problem of nuclide exposure results in genetic alteration and can lead to congenital anomalies in the second and subsequent generations. ${ }^{[1]}$ Exposure to radiation of more than $10 \mathrm{cGy}$ is known to induce genetic alteration, which can lead to congenital disorders such as cleft lip, cleft palate and hydronephrosis. ${ }^{[2]}$ Plastic surgery plays an important role in the surgical correction of many conditions that have an increased frequency in post-nuclear crisis situation (such as hydronephrosis, ${ }^{[3]}$ cleft lip $^{[4]}$ and cleft palate $\left.{ }^{[4]}\right)$. The increased incidence of skin cancer in post irradiated cases requires a special mention. Basal cell carcinoma is reported as an important cancer in exposed subjects and long-term follow-up for skin cancer development is recommended in populations in contaminated areas. ${ }^{[5]}$ Plastic surgery also plays a role in the management of such cancers.

A major concern is of the outcome of plastic surgery in radiation exposed subjects. In the post-operative phase there are more frequent complications because 
of subnormal immunity. ${ }^{[3]}$ However, based on the observation on radical plastic operation in the postChernobyl crisis situation, there is no relationship between outcome to radiation exposure level and severity of the disease. ${ }^{[3]}$ Hence, in the present 2011 nuclear crisis, special care and close follow-up might be required in plastic surgery cases in contaminated areas. Finally, the new approach via using new mesenchymal stem cell application can be the new hope for improving the outcome of plastic surgery in these individuals. ${ }^{[6]}$

\section{Viroj Wiwanitkit}

Wiwanitkit House, Bangkhae, Bangkok, Thailand

Address for correspondence: Prof. Viroj Wiwanitkit, Wiwanitkit House, Bangkhae, Bangkok, Thailand 10160. E-mail: wviroj@yahoo.com

\section{REFERENCES}

1. Feshchenko SP, Schröder HC, Müller WE, Lazjuk GI. Congenital malformations among newborns and developmental abnormalities among human embryos in Belarus after Chernobyl accident. Cell Mol Biol (Noisy-legrand) 2002;48:423-6.

2. Liaginskaia AM, Tukov AR, Osipov VA, Prokhorova ON. Genetic effects in the liquidators of consequences of Chernobyl Nuclear Power Plant accident. Radiats Biol Radioecol 2007;47: 188-95.

3. Karpenko VS. Principle of hydronephrosis and choice of surgical method. Urologiia 2002;3:43-6.

4. Khonsari RH, Ivanov AL. Cleft lip and palate surgery in Russia. Rev Stomatol Chir Maxillofac 2008;109:343-5.

5. Steinert M, Weiss M, Gottlöber P, Belyi D, Gergel O, Bebeshko $\mathrm{V}$, et al. Delayed effects of accidental cutaneous radiation exposure: Fifteen years of follow-up after the Chernobyl accident. J Am Acad Dermatol 2003;49:417-23.

6. Müller K, Meineke V. Advances in the management of localized radiation injuries. Health Phys 2010;98:843-50.

\begin{tabular}{|l|l|}
\multicolumn{3}{|c|}{ Access this article online } \\
\hline Quick Response Code: & Website: \\
\hline & www.ijps.org \\
\cline { 2 - 2 } & DOI: \\
\hline
\end{tabular}

\section{Notice}

With reference to the article "Trapezio-metacarpal arthritis - The price of an opposable thumb!" authored by Tolga Turker and Sunil Thirkannad and published in IJPS Vol. 44 issue 2, 2011, Dr Luis R. Scheker of the Christine M. Kleinert Institute , Louisville has pointed to us that some figures and matter from one of his articles has been used in this paper and has not been referenced. We are publishing the response from Dr Thirkanand regarding the issue and hope due credit is rendered to all concerned.

Editor

Indian Journal of Plastic Surgery.

To,

The Editor, I.J.P.S.

RE: ““'Trapezio-metacarpal arthritis: The price of an opposable thumb!” - Turker T and Thirkannad SM. IJPS, 44:308, 2011

Dear Sir,

As corresponding and senior author of the above mentioned review article, I am writing to inform you of a clarification regarding the same. Some of the illustrations used in our aricle have previously been used in publications genereated from our institute. They are as follows:

1) Figure 1 of our paper was redrawn and modified from Figure 1 of the article: Functional Anatomy of the Hand. Belliappa PP and Scheker LR. Emergency Medicine Clinics of North America (1993) 11:557-583.

2) Figure 7 is a clinical photograph of a patient belonging to Dr. Luis Scheker and should be referenced as "courtesy of LR Scheker".

3) Figure 9, 10 and 11 have previously been used in the following article: Dynamic suspension-sling arthroplasty with intermetacarpal ligament reconstruction for the treatment of trapeziometacarpal osteoarthritis. Scheker LR and Boland MR. Eur J. Plast Surg (2004) 27:185.

I request you to kindly publish this erratum so that Dr. Scheker \& our Institute can receive due credit. I apologize for this initial omission on our part.

Sincerely,

Sunil M. Thirkannad, MD

Christine M. Kleinert Institute for Hand \& Microsurgery

Louisville, USA 